\title{
A survey of French general practitioners on the epidemiology of wounds in family practice
}

This article was published in the following Dove Press journal:

International Journal of General Medicine

16 June 2015

Number of times this article has been viewed

\author{
Marianne Sarazin ${ }^{1-3}$ \\ Florence Roberton 4 \\ Rodolphe Charles ${ }^{4}$ \\ Alessandra Falchi ${ }^{1,2,5}$ \\ Solange Gonzales Chiappe ${ }^{1-3}$ \\ Thierry Blanchon ${ }^{1,2}$ \\ Frédéric Lucht ${ }^{6}$ \\ Thomas Hanslik $1,2,7,8$ \\ 'INSERM, UMR_S II36, F-750I2, \\ Paris, France; ${ }^{2}$ Sorbonne Universités, \\ UPMC University Paris 06, UMR_S \\ II 36, F-750 I2, Paris, France; ${ }^{3}$ DIM, \\ Centre Hospitalier, 42700 Firminy, \\ France; ${ }^{4}$ Département de médecine \\ générale, Faculté de médecine Jacques \\ Lisfranc, F-42023 Saint Etienne, \\ CE France; ${ }^{5} \mathrm{EA} 7310$, Laboratoire \\ de Virologie, Université de Corse, \\ F-20250 Corte, France; ${ }^{6} \mathrm{CIC}$-EC3, \\ CHU Saint Etienne, F-42277 Saint- \\ Priest en Jarez, CE France; ${ }^{7}$ UVSQ, \\ Université de Versailles Saint Quentin, \\ F-78000 Versailles, France; ${ }^{8}$ Assistance \\ Publique Hôpitaux de Paris, service de \\ Médecine Interne, Hôpital Ambroise \\ Paré, F-92100 Boulogne Billancourt, \\ France
}

Correspondence: Marianne Sarazin Département d'information médicale, Centre Hospitalier, Rue de Bénaud, 42700 Firminy, France

Tel +33 47I 407 I05

Email msarazin@u707.jussieu.fr
Background: To measure the frequency and nature of wounds in patients treated in general practice and to describe the patients' tetanus vaccination status and the sources providing information about this status.

Methods: A descriptive, prospective, week-long, national electronic survey was conducted among general practitioners within the Sentinelles network.

Results: The participation rate was $12.6 \%$ (95\% confidence interval [CI], 10.6\%-14.6\%; 130 general practitioners): 197 patients with wounds were reported, and 175 of them were described. Wound frequency was $1.4(95 \%$ CI, 1.2-1.6) per 100 consultations. These wounds had an acute character in $76(95 \% \mathrm{CI}, 69.7-82.3)$ of cases, were mostly of traumatic origin $(54.8 \%$ of cases; 95\% CI, 47.5\%-62.1\%), were more than 24 hours old (67.1\%; 95\% CI, 59.1\%-75.1\%), and were clean, without bone and/or muscle decay (94\%; 95\% CI, 90.5\%-97.5\%). Vaccination status was known for 71 (95\% CI, 64-78) patients. According to the 2013 immunization schedule, $21 \%(95 \% \mathrm{CI}, 13.9 \%-28.1 \%)$ of the patients had not updated their vaccinations, mostly among the patients older than 75 years.

Conclusion: This survey describes in detail the wounds treated in general practice in France and the associated patients' immunization status. It also shows how difficult it is for general practitioners to assess the risk of contracting tetanus and the disease's development. It highlights as well the fact that the ideal solution to assess tetanus risk is an up-to-date immunization schedule.

Keywords: general practice, tetanus, wound, incidence

\section{Introduction}

Tetanus is a severe acute infection caused by the exotoxins produced by an anaerobic, gram-positive bacillus. In developed countries, tetanus still is a frequently fatal disease. Its incidence in France is 0.14 cases per million inhabitants. The rate of death from tetanus is $32 \%$ among cases reported in recent years. ${ }^{1}$ Most tetanus cases (approximately $70 \%-80 \%$ of cases) result from minor wounds (cuts, scratches, and so on). However, chronic wounds (varicose ulcers, bedsores, etc) also present a significant risk factor $(10 \%-15 \%$ of cases $)$. Women and people older than 70 years are more easily affected. ${ }^{2-5}$

Tetanus vaccination is the only effective prevention. Since 1952, when infant vaccination became mandatory in France, the incidence of tetanus has dropped significantly, going from 25 to 0.5 cases per million people. Various immunization policies have been proposed, the most recent in $2013,{ }^{6}$ yet many people still are not fully protected. ${ }^{7-10}$ 
It is difficult to assess a patient's tetanus immunization status when one relies only on the patient's testimony. ${ }^{4,7-10}$ As a consequence, when in doubt, physicians often choose to give one or more preventive injections when they treat the wound of a patient at risk for tetanus. A strategy for the prophylaxis and therapy of tetanus has been developed by the French National Health Authorities that includes, for emergency services only, immunochromatographic testing. The medical and economic value of these tests has been assessed in that context. ${ }^{11-14}$ The tests quickly determine the patient's immune status and present real advantages over the preventive injection of immunoglobulins. ${ }^{3,11-13}$ In France, the lack of epidemiological data on the wounds treated in general practice limits the application of those tests outside the hospital setting.

The current overcrowding of emergency services has led to public health policies that focus on general practitioners (GPs), as they are the primary care providers, and the strategies used in emergency services, including immunochromatographic testing, should also be applied to general practices. To optimize wound management in general practice, an epidemiological study was conducted in France, including vaccination status and taking into account vaccination schedule changes after the study period.

\section{Method}

\section{Type of survey}

Cross-sectional study was conducted among GPs in France.

\section{Participants}

GPs who are members of the French Sentinelles Network, a national system for the electronic monitoring of diseases, ${ }^{15,16}$ were invited to participate in an online survey in June 2012 ( $n=1,028$ GPs). All GPs who were members of the French Sentinelles Network volunteers could participate without any inclusion or exclusion criteria. They could connect to a platform, using a single password that allowed them to participate only once. Those GPs received reminders to participate for 3 consecutive weeks. French Sentinelles Network members are representative of the global French GP population regarding age, location (rural/urban), and type of practice (single/ two or more physicians). The French Sentinelles Network received formal approval for this study from the National Ethics Committee (Commission nationale de l'informatique et des libertés, CNIL 471393). All data were handled confidentially, and the results were anonymous

\section{Data collection}

Data were collected on all patients' wounds treated by GPs over the course of 1 week of consultation, in or out of the office. A wound was defined as any break in the skin barrier that caused bleeding or exposed dermis. The questionnaire contained five parts:

1. Context of the GP's consultation: reason for the consultation, place, date, and hour; emergency or not; GP's status (family physician or other); and access to the patient's file at the time of consultation.

2. The patient's characteristics: age, sex, weight, height, associated diabetes, addictions, or consumption of toxic substances by injection.

3. Description of wound: location, context of occurrence, size, damaged elements (muscle, skin, etc), cleanliness, and time elapsed since trauma; acute (burn, traumatic wound, postsurgical wound) or chronic (venous ulcer, diabetic plantar ulcer, or other wound whose healing time is more than 4-6 weeks).

4. The GP's identification of tetanus risk using a scale describing the wound as major risk, minor risk, or no risk for tetanus. ${ }^{3,4}$

5. The patient's immunization status: date of last vaccination and description of documentation used for that identification (health record, vaccination record, computerized patient record, etc).

An additional survey was carried out among a random sample of 50 nonparticipating GPs to determine their reasons for nonparticipation.

\section{Analysis of results}

The incidence of wounded patients was estimated from the average number of treated patients per GP and the average number of weekly consultations (including home visits) for each GP. The GP's French representativeness was obtained from the French Health Research department. ${ }^{17}$ The information was obtained from the Survey of Individual Activity and Prescription and was provided by the national French health insurance Caisse nationale d'Assurance maladie (CNAM) for each participating GP. ${ }^{18}$

All variables in this study were analyzed using the $R^{\circledR}$ software program (http://www.r-project.org/). Categorical variables were compared using the Chi-square test or Fisher's exact test, and continuous variables were compared using a Student's $t$-test. Logistic regression analysis was used to study the GP's tetanus risk identification.

\section{Results}

\section{Participation and characteristics of GPs}

A total of 130 GPs participated in the study, representing a participation rate of $12.6 \%$ ( $95 \%$ confidence interval [CI], $10.6 \%-14.6 \%$ ) of the GPs invited to complete the survey. Of those reporting, 92 GPs $(70.1 \%)$ treated at least one patient 
Table I General practitioners participation

\begin{tabular}{lllllll}
\hline $\begin{array}{l}\text { French } \\
\text { general } \\
\text { practitioners }\end{array}$ & $\begin{array}{l}\text { General practitioners, } \\
\text { member of French } \\
\text { Sentinelles Network with } \\
\text { valid electronic address }\end{array}$ & $\begin{array}{l}\text { Participants } \\
\text { general } \\
\text { practitioners }\end{array}$ & $\begin{array}{l}\text { Participant general } \\
\text { practitioners with } \\
\text { all records fully } \\
\text { completed }\end{array}$ & Patients & Consultations & $\begin{array}{l}\text { Wounds } \\
\text { described }\end{array}$ \\
\hline 57,922 & 1,028 & 130 & 124 & 197 & $14,07 \mid$ & 175 \\
\hline
\end{tabular}

with a wound (Table 1); 38 GPs (29.9\%) did not treat any patients with wounds.

Participating GPs were mostly male (sex ratio, 3.4:1), had an average age of 53.8 years (95\% CI, 52.4-55.2 years), and ran a rural practice (63.1\%). Eighty-two GPs had a rural practice, and 48 had an urban one.

There was no significant difference between the participating and nonparticipating sample GPs and those of the French Sentinelles Network in terms of average age and sex ratio, but participating GPs had a more significant rural practice (Table 2).

Reasons for nonparticipation reported by the 50 nonparticipating GPs were no patient seen with a wound during the studied period $(66 \% ; n=33)$, out of office during the studied period $(18 \% ; n=9)$, lack of time to complete the survey $(2 \% ; n=1)$, and unspecified refusal $(14 \% ; n=7)$.

\section{Patient characteristics}

A total of 197 patients with at least one wound were reported, which led to a frequency of $1.4(95 \% \mathrm{CI}, 1.2-1.6)$ cases per 100 consultations. This frequency was significantly higher among GPs with an urban practice (1.67 [95\% CI, 1.27-2.07] vs 1.55 [95\% CI, 1.35-1.75] in rural areas; $P<0.05$ ).

These wounds were treated during a consultation carried out by their family GP (88\%), in the GP's office $(74.9 \%$

Table 2 Characteristics of respondent general practitioners in the study compared with those of French metropolitan general practitioners

\begin{tabular}{|c|c|c|c|}
\hline Characteristic & $\begin{array}{l}\text { Respondent general } \\
\text { practitioners } \\
(\mathrm{N}=\mid 30)\end{array}$ & $\begin{array}{l}\text { French general } \\
\text { practitioners } \\
(\mathrm{N}=57,922)^{17}\end{array}$ & $P$-value \\
\hline \multicolumn{4}{|l|}{ Sex } \\
\hline Men & $101(78 \%)$ & $39,27 \mid(67.8 \%)$ & $<0.05$ \\
\hline Women & $29(22 \%)$ & $|8,65|(32.2 \%)$ & \\
\hline \multicolumn{4}{|l|}{ Age } \\
\hline $\begin{array}{l}\text { Average } \\
\text { (years) }\end{array}$ & $\begin{array}{l}53.8 \pm 1.8 \text { (minimum, } \\
30 \text { years; maximum, } \\
72 \text { years) }\end{array}$ & 51.3 & \\
\hline \multicolumn{4}{|l|}{ Practice location } \\
\hline Rural & $82(63.1 \%)$ & $9,44 \mid(16.3 \%)$ & $<0.05$ \\
\hline Urban & 48 (36.9\%) & $48,48 \mathrm{I}(83.7 \%)$ & \\
\hline \multicolumn{4}{|l|}{ Practice type } \\
\hline Individual & 60 (46\%) & 31,915 (55.1\%) & $<0.05$ \\
\hline Group & $70(54 \%)$ & 26,007 (44.9\%) & \\
\hline
\end{tabular}

Note: Source: DREES. ${ }^{17}$ of cases), or during a scheduled consultation $(62.3 \%$ of cases). The wounds were usually the main reason for the consultation ( $67.4 \%$ of cases).

Of the 197 patients, 175 were fully described: 118 were seen by GPs with a rural practice and 79 by GPs with an urban practice. These patients had an average age of 50.8 years, with a homogeneous age distribution ( $<20$ years, $20 \%$; $20-40$ years, $17 \%$; $40-60$ years, $20 \%$; $60-80$ years, $24 \%$; $>80$ years, $19 \%$ ), the sex ratio was three women to one man. Diabetes was present in $13.1 \%$ of the cases and obesity in $14.3 \%$ of the cases. They were wounded in an environment that facilitated contact with the tetanus bacteria (activity or outdoor recreation and/ or presence of animals) in $40.6 \%$ of cases.

The patients had from one to more than three wounds ( $76 \%$ and $9.7 \%$ of cases, respectively). These wounds were the result of an outdoor activity in $25.1 \%$ of cases. They had been inflicted more than 12 hours before treatment in $74 \%$ of cases and had no significant relation with the context of the consultation (scheduled or emergency, $P<0.05$ ). They were mostly traumatic ( $54.8 \%$ of cases) and were considered to be clean ( $94 \%$ of cases), and most often they were located on the lower limbs ( $46.8 \%$ of cases).

\section{Wound characteristics}

Most patients (76\%; 95\% CI, 69.7\%-82.3\%) had only one wound, mainly caused by trauma $(54.8 \% ; 95 \%$ CI, 47.5\%-62.1\%), principally acute (76\%; 95\% CI, $69.7 \%-82.3 \%)$, and were generally considered clean $(94 \%$; 95\% CI, 90.5\%-97.5\%) and without any significant difference between rural and urban practice (Table 3 ).

These wounds mainly sat on the lower limb (46.8\%; 95\% CI, 39.4\%-54.2\%), upper limb (29.6\%; 95\% CI, $22.8 \%-36.4 \%)$, trunk (12.1\%; 95\% CI, 7.3\%-16.9\%), and head $(11.5 \%$; 95\% CI, 6.8\%-16.2\%).

Acute wounds were more than 24 hours old in $67.1 \%$ (95\% CI, 59.1\%-75.1\%) of cases; chronic wounds were more than 1 month old in all cases.

\section{The physicians' identification of tetanus risk}

Of the wounds, $30.8 \%$ were classified as "no risk" for transmission of tetanus, $60.6 \%$ as "minor risk," and $8.6 \%$ as "major risk." Wounds classified as major risk were mostly 
Table 3 Characteristics of wounds of the 175 patients included in the survey and for whom a description has been fully completed

\begin{tabular}{|c|c|c|}
\hline Wound aspect $(\mathrm{N}=\mid 75)$ & $\mathbf{N}$ & $\%$ \\
\hline Clean & 165 & 94.3 \\
\hline Soiled (metallic/organic extracorporeal materials) & 3 & 1.7 \\
\hline Soiled (saliva, ground particles, excrements) & 7 & 4.0 \\
\hline \multicolumn{3}{|l|}{ Wound location (several locations possible) $(\mathrm{N}=199)$} \\
\hline Leg/foot & 93 & 46.8 \\
\hline Arm/hand & 59 & 29.6 \\
\hline Torso & 24 & 12.1 \\
\hline Head & 23 & 11.5 \\
\hline \multicolumn{3}{|l|}{ Wound type $(\mathrm{N}=175)$} \\
\hline Acute & 133 & 76.0 \\
\hline Chronic & 42 & 24.0 \\
\hline \multicolumn{3}{|l|}{ Decay $(\mathrm{N}=175)$} \\
\hline Muscles & 7 & 4.0 \\
\hline Bone & 2 & 1.1 \\
\hline \multicolumn{3}{|l|}{ Wound context $(\mathrm{N}=175)$} \\
\hline Traumatic & 96 & 54.8 \\
\hline Incision & 31 & 17.7 \\
\hline Sting & 6 & 3.4 \\
\hline Excoriation & 29 & 16.6 \\
\hline Bite & 7 & 4 \\
\hline Crush & 23 & 13.1 \\
\hline Nontraumatic & 36 & 20.0 \\
\hline Venous ulcer & 12 & 6.6 \\
\hline Diabetic plantar ulcer & I & 0.6 \\
\hline Necrotic ulcerative lesion & 19 & 10.4 \\
\hline Second to third degree burn & 4 & 2.2 \\
\hline Postsurgery & 14 & 8 \\
\hline Oozing lesion & 3 & 2.2 \\
\hline Reopened lesion & 5 & 2.8 \\
\hline Other postsurgery lesion & 6 & 3.3 \\
\hline Not specified & 29 & 16.6 \\
\hline
\end{tabular}

clean traumatic wounds with muscle damage. A favorable environmental context (with "risky" occupation or leisure activities increasing the risk for contact with a telluric germ) was the only factor significantly associated with a minor or major tetanus risk $(P<0.05)$. The other criteria (cleanliness, location on the body, wait time before treatment, and patient's immunization status) were not significant in the physicians' identification of tetanus risk (Table 4).

\section{Patients' tetanus immunization}

The GPs ascertained the immunization status directly from the patient ( $12.9 \%$ of cases) or through the patient's health record (22.6\% of cases), the patient's immunization record ( $1 \%$ of cases), or the patient's computerized record $(66.1 \%$ of cases), with the possibility of accessing several of these sources (Table 5).

The date of last tetanus immunization was known for $71 \%$ of patients. Among those patients, $79 \%$ were up-to-date with the immunization schedule recommended at the time of the survey.
Table 4 Identification of tetanus risk by general practitioners, depending on wound context

\begin{tabular}{|c|c|c|c|c|}
\hline Wound context & $\begin{array}{l}\text { No risk, } \\
\mathrm{N}=54 \text { (\%) }\end{array}$ & $\begin{array}{l}\text { Minor risk, } \\
\mathrm{N}=106 \text { (\%) }\end{array}$ & $\begin{array}{l}\text { Major risk, } \\
\mathrm{N}=15 \text { (\%) }\end{array}$ & $P$-value \\
\hline Clean & $53(98)$ & 101 (95) & II (73) & $<0.05$ \\
\hline Soiled & I (2) & $5(5)$ & $4(27)$ & \\
\hline $\begin{array}{l}\text { Acute wound } \\
<24 \text { hours before } \\
\text { treatment }\end{array}$ & $14(37)$ & $30(36)$ & $4(3 I)$ & $>0.05$ \\
\hline $\begin{array}{l}\text { Acute wound } \\
>24 \text { hours before } \\
\text { treatment }\end{array}$ & $24(63)$ & $53(64)$ & $9(69)$ & \\
\hline $\begin{array}{l}\text { Up-to-date } \\
\text { vaccination }\end{array}$ & $32(59)$ & $63(59)$ & $10(67)$ & $>0.05$ \\
\hline $\begin{array}{l}\text { Non up-to-date or } \\
\text { unknown vaccination }\end{array}$ & $22(4 I)$ & $43(4 I)$ & $5(33)$ & \\
\hline $\begin{array}{l}\text { Body mass index } \\
>30 \mathrm{~kg} / \mathrm{m}^{2}\end{array}$ & $8(15)$ & $15(14)$ & $2(13)$ & $>0.05$ \\
\hline $\begin{array}{l}\text { Body mass index } \\
<30 \mathrm{~kg} / \mathrm{m}^{2}\end{array}$ & $46(85)$ & $91(86)$ & $13(87)$ & \\
\hline $\begin{array}{l}\text { Bone or muscle } \\
\text { deterioration }\end{array}$ & 3 & 5 & 0 & NA \\
\hline No deterioration & 51 & 96 & 15 & NA \\
\hline Outdoor activity & $5(9)$ & $3 I(3 I)$ & $6(40)$ & $>0.05$ \\
\hline Nonoutdoor activity & $49(91)$ & $70(69)$ & $9(60)$ & \\
\hline
\end{tabular}

Abbreviation: NA, not available.

According to the French National Health recommended schedule of $2013,{ }^{6}$ the percentage of those patients rose to $90.3 \%$. Each age group showed this increase with the exception of the group of patients older than 75 years, in which $75.9 \%$ of the patients had immunizations considered to be up-to-date for the 2012 schedule, dropping to $58.4 \%$ for the 2013 schedule.

\section{Discussion}

This study describes for the first time in France the epidemiology of wounds in general practice and the status of tetanus immunization in this context.

The frequency of wounds observed in general practice (1.4\% of consultations) remains significantly lower than

Table 5 Patients' known immunization status by age, according to the 2012 vaccination schedule $(n=124)$

\begin{tabular}{lllll}
\hline $\begin{array}{l}\text { Age } \\
\text { group, } \\
\text { years }\end{array}$ & $\mathbf{n}$ & $\begin{array}{l}\text { Up-to-date } \\
\text { vaccination } \\
(\mathbf{n}=\text { I I })\end{array}$ & $\begin{array}{l}\text { Non-up-to-date } \\
\text { vaccination } \\
(\mathbf{n = 1 2})\end{array}$ & $\begin{array}{l}\text { Percentage of } \\
\text { non-up-to-date } \\
\text { vaccination }\end{array}$ \\
\hline$<11$ & 19 & 18 & 1 & $5.3 \%$ \\
$11-13$ & 3 & 2 & 1 & $33.3 \%$ \\
$14-25$ & 12 & 11 & 1 & $8.3 \%$ \\
$26-45$ & 16 & 14 & 2 & $12.5 \%$ \\
$46-65$ & 32 & 25 & 7 & $21.9 \%$ \\
$66-75$ & 13 & 11 & 2 & $15.4 \%$ \\
$76-85$ & 19 & 15 & 4 & $15.8 \%$ \\
$>85$ & 10 & 7 & 3 & $30.0 \%$ \\
\hline
\end{tabular}


that observed in the emergency departments $(13 \%)^{7,8}$ These results merit discussion: one of the reasons for a nonresponse from the nonparticipants (nonparticipating study) was that no wounds were treated in consultation. This may have induced an overevaluation of frequency in this study. The season when the patient was wounded may also have contributed to the incidence reported here, as the study was conducted neither in the summertime nor during a holiday period, when a greater frequency of outdoor activities can foster their occurrence. ${ }^{19}$ The representativeness of participating GPs can also be discussed. Compared with the overall population of French GPs, the GPs of this study were slightly older ( 54 vs 51 years), there were more men than women ( $78 \%$ vs $68 \%$ ), and they had a mostly rural practice (63\% vs $16 \%)$.

Although a higher incidence of wounds seen in rural areas could be expected ${ }^{20}$ (because of the remoteness of the emergency department), this study showed the opposite. The small sample and lack of GP representativeness on the criterion of urban or rural practice may explain these results. However, the greater number of participating GPs with a rural practice shows that they seem more concerned with this problem. The more autonomous patients' behavior in rural areas was related to a medical shortage in urban areas in France; distance may also contribute to these results. In urban areas, a large number of patients and waiting times in emergency departments can provide the opposite behavior. This study shows the difficulties the GPs had to assess a tetanus risk which are the same as those faced by emergency practitioners. In the GPs opinion, the only parameter associated with a perceived high risk for tetanus was the patient's profession or choice of "risky" leisure activity. The clinical aspect of the wound was not identified as a risk factor. To our knowledge, the concept of tetanus risk has yet to be validated by a consensual definition, which can explain why these physicians developed their own conception of tetanus risk. This discrepancy has already been mentioned in another French study. ${ }^{5}$ With the perspective of better wound management, and in accordance with the principles of evidence-based medicine, ${ }^{21}$ tetanus risk identification based only on the physicians' opinion is unlikely to continue in practice.

Gathering information on their patients' tetanus vaccination history was difficult for the GPs in this study. This supports the results of the previous studies performed in emergency departments. ${ }^{5,7,22-25}$ Finding immunization information requires the medical attendants to access several sources (paper documentation or computerized reports), as currently $30 \%$ of patients are still unaware of their vaccination status. Electronic devices are being used more frequently in patients' treatment, and as patient electronic medical recording has recently become compulsory (by now, more than $80 \%{ }^{26}$ of GPs participate), this might improve the recordkeeping of patients' immunization status and their follow-up. Moreover, the new immunization schedule, based on age groups, will probably improve vaccination coverage in the future. It is difficult for a GP to assess a patient's tetanus risk and know their immunization status when they display one or more wounds, whatever the aspect of the wounds. Thus, under these conditions, immunochromatographic testing seems to be of a great interest for wound management in general practice. At present the tests are only available for emergency use in France. According to the incidence found in this study and the population of French GPs, GPs perform consultations on about 300,000 wounds each year. Among those wounds, 50,000 could be considered without any tetanus immunization. ${ }^{23}$ Thus, immunochromatographic testing would be useful to avoid immunoglobulin injections as a preventive and more expensive therapy. However, immunochromatographic testing remains to be evaluated in that context in France. Easy to perform and inexpensive, its implementation in general practice may also optimize the economic management of wounds, as is done in emergencies departments.

Above all, it is necessary to increase compliance with the recommendations of tetanus vaccination that could improve territorial coverage and vaccination follow-ups. This probably constitutes the best way for an effective primary prevention of wound-induced tetanus.

\section{Conclusion}

Wounds' incidence in general practice remains sufficient to be considered. The main problem of their management is the assessment of tetanus risk and vaccination, as information has not yet been collected on a centralized site.

Immunochromatographic testing could be interesting as preventive therapy in that context, as it is not yet allowed in general practice in France. Above all, more information on vaccination follow-up and prevention are the best primary prevention.

\section{Author contributions}

All authors made substantial contributions to conception and design, acquisition of data, or analysis and interpretation of data; took part in either drafting the article or revising it critically for important intellectual content; gave final approval of the version to be published; and agree to be accountable for 
all aspects of the work in ensuring that questions related to the accuracy or integrity of any part of the work are appropriately investigated and resolved.

\section{Acknowledgments}

The authors thank all of the general practitioners in the Sentinelles network who participated in the survey.

\section{Disclosure}

The authors report no conflicts of interest in this work.

\section{References}

1. Antona D. Tetanus in France between 2008 and 2011. Available from: http://www.invs.sante.fr/Publications-et-outils/BEHBulletin-epidemiologique-hebdomadaire/Archives/2012/BEH-n-262012. Accessed November 27, 2014.

2. Henderson SO, Mody T, Groth DE, Moore JJ, Newton E. The presentation of tetanus in an emergency department. J Emerg Med. 1998;16(5): 705-708.

3. Guide des vaccinations. Direction générale de la santé, Comité technique des vaccinations; 2012. Available from: http://www.inpes.sante.fr/ CFESBases/catalogue/pdf/1133.pdf. Accessed November 27, 2014.

4. Mise en évidence de l'immunoprotection antitétanique en contexte d'urgence. Note de cadrage de la Haute autorité de santé, Décembre 2009. Available from: http://www.has-sante.fr/portail/upload/docs/ application/pdf/200912/mise_en_evidence_de_limmunoprotection_ antitetanique_en_contexte_durgence-note_de_cadrage.pdf. Accessed November 27, 2014.

5. Barjat C, Charles R, Lucht F, Frappé P. Gestion du risque tétanique des plaies en médecine générale [Managing the risk of wound tetanus in family practice]. Med Mal Infect. 2011;41(8):424-429. French.

6. 2013 vaccination schedule and recommendations from the "Haut Conseil de la Santé Publique" in France. Available from: http://www.invs.sante. fr/Publications-et-outils/BEH-Bulletin-epidemiologique-hebdomadaire/ Archives/2013/BEH-n-14-15-2013. Accessed November 27, 2014.

7. Abbate R, Di Giuseppe G, Marinelli P, Angelillo IF; Collaborative Working Group. Appropriate tetanus prophylaxis practices in patients attending Emergency Departments in Italy. Vaccine. 2008;26(29-30): 3634-3639.

8. Auffret Y, Jacolot L, Jestin B, et al. Quelle prophylaxie tétanos aux urgences? [Tetanus prophylaxis in emergency departments]. Rev Prat. 2008;58(6):585-589. French.

9. Martinot A, Cohen R, Denis F, et al. Vaccinoscopie $\left({ }^{\circledR}\right)$ : étude de l'évolution annuelle entre 2008 et 2011 de la couverture vaccinale des enfants de moins de 7 ans dans la population française [Annual trends (2008-2011) in early childhood vaccination coverage for the French population: the Vaccinoscopie $\left({ }^{\circledR}\right)$ study]. Arch Pediatr. 2013;20(8): 837-844. French.

10. Moore MA, Barber KR, Britt T. Tetanus seropositive prevalence and perceived protection from emergency admissions. Emerg Health Threats J. 2012;5(0):5.

International Journal of General Medicine

\section{Publish your work in this journal}

The International Journal of General Medicine is an international, peer-reviewed open-access journal that focuses on general and internal medicine, pathogenesis, epidemiology, diagnosis, monitoring and treatment protocols. The journal is characterized by the rapid reporting of reviews, original research and clinical studies across all disease areas.
11. Troël E, Hamon X, Tran D, Pondaven C, Tréguer J. Optimisation de l'utilisation du tétanos Quick Stick(TQS) dans la prophylaxie antitétanique. J Eur Urgences. 2008;21:A51-A5.

12. McVicar J. Should we test for tetanus immunity in all emergency department patients with wounds? Emerg Med J. 2013;30(3):177-179.

13. Elkharrat D, Sanson-Le-Pors MJ, Arrouy L, Beauchet A, Benhamou F. Evaluation of a bedside immunotest to predict individual anti-tetanus seroprotection: a prospective concordance study of 1018 adults in an emergency department. Emerg Med J. 2010;27(1):36-42.

14. Stubbe M, Mortelmans LJ, Desruelles D, et al; Belgian Society of Emergency and Disaster Medicine. Improving tetanus prophylaxis in the emergency department: a prospective, double-blind cost-effectiveness study. Emerg Med J. 2007;24(9):648-653.

15. Flahault A, Blanchon T, Dorléans Y, Toubiana L, Vibert JF, Valleron AJ. Virtual surveillance of communicable diseases: a 20-year experience in France. Stat Methods Med Res. 2006;15(5):413-421.

16. Cantarelli P, Debin M, Turbelin C, et al. The representativeness of a European multi-center network for influenza-like-illness participatory surveillance. BMC Public Health. 2014;14(1):984.

17. Sicart D. Les médecins :estimations au 1er janvier 2009. Available from: http://www.drees.sante.gouv.fr/les-medecins-estimations-au-1erjanvier-2009,5182.html. Accessed November 27, 2014.

18. French Health insurance. Available from: http://www.ameli.fr/ professionnels-de-sante/medecins/gerer-votre-activite/votre-exerciceen-liberal/. Accessed November 27, 2014.

19. Foltran F, Avossa F, Fedeli U, Baldi I, Spolaore P, Gregori D. Seasonal variations in injury rates in children: evidence from a 10-year study in the Veneto Region, Italy. Int J Inj Contr Saf Promot. 2013;20(3): 254-258.

20. Probst JC, Moore CG, Baxley EG, Lammie JJ. Rural-urban differences in visits to primary care physicians. Fam Med. 2002;34(8):609-615.

21. Guyatt G; Evidence-Based Medicine Working Group. Evidence-based medicine. A new approach to teaching the practice of medicine. JAMA. 1992;268(17):2420-2425.

22. Beytout J, Denis F, Giet R, Allaert FA. Variations régionales du statut vaccinal de la population adulte [Regional variations of adult population vaccinal status]. Med Mal Infect. 2004;34(10):460-468. French.

23. Guthmann JP, Fonteneau L, Antona D, Lévy-Bruhl D. Déterminants de couverture vaccinale antitétanique chez l'adulte en France et de connaissance du statut vaccinal [Factors associated with tetanus vaccination coverage in adults in France and with knowledge of vaccination status]. Med Mal Infect. 2010;40(10):560-567. French.

24. Jestin C. Obligatoire ou recommandées, les vaccinations sont elles bien pratiquées en France? Solidarité Santé Études Stat. 1990;3-4:19-33.

25. McQuillan GM, Kruszon-Moran D, Deforest A, Chu SY, Wharton M. Serologic immunity to diphtheria and tetanus in the United States. Ann Intern Med. 2002;136(9):660-666.

26. European Commission Benchmarking. Benchmarking ICT use among General Practitioners in Europe 2007, Country Profile: France. European Commission, Information Society and Media Directorate General; 2008. Available from: http://www.i-med.fr/IMG/pdf/INDeH_CountryProfile_ France.pdf. Accessed August 28, 2014.
A key focus is the elucidation of disease processes and management protocols resulting in improved outcomes for the patient.The manuscript management system is completely online and includes a very quick and fair peer-review system. Visit http://www.dovepress.com/ testimonials.php to read real quotes from published authors. 